\title{
METHODS OF OVERCOMING DORMANCY IN Schizolobium amazonicum Huber ex Ducke (LEGUMINOSAE - CAESALPINIOIDEAE) SEEDS ${ }^{1}$
}

\author{
ENIELDAVID CRUZ², JOSÉ EDMARURANODE CARVALHO²
}

\begin{abstract}
Seed dormancy is a frequent phenomenon in tropical species, causing slow and non-uniform germination. To overcome this, treatments such as scarification on abrasive surface and hot water are efficient. The objective of this study was to quantify seed germination with no treatment (Experiment 1) and identify an efficient method of breaking dormancy in Schizolobium amazonicum Huber ex Ducke seeds (Experiment 2). The effects of manual scarification on electric emery, water at $80^{\circ} \mathrm{C}$ and $100^{\circ} \mathrm{C}$ and manual scarification on wood sandpaper were studied. Seeds were sown either immediately after scarification or after immersion in water for $24 \mathrm{~h}$ in a sand and sawdust mixture. Germination and hard seed percentages and germination speed were recorded and analyzed in a completely randomized design. Analysis of germination was carried out at six, nine, 12, 15, 18, 21 and 24 days after sowing as a 4x2 factorial design and through regression analysis. Treatment means of the remaining variables were compared by the Tukey test. Seed germination with no treatment started on the $7^{\text {th }}$ day after sowing and reached $90 \%$ on the $2310^{\text {th }}$ day (Experiment 1). Significant interaction between treatments to overcome dormancy and time of immersion in water was observed (Experiment 2). In general, immersion in water increased the germination in most evaluations. The regression analyses were significant for all treatments with exception of the control treatment and immersion in water at $80^{\circ} \mathrm{C}$. Germination speed was higher when seeds were scarified on an abrasive surface (emery and sandpaper) and, in these treatments, the germination ranged from $87 \%$ to $96 \%$, with no hard seeds. S. amazonicum seeds coats are impermeable to water, which hinders quick and uniform germination. Scarification on electric emery followed by immediate sowing, scarification on sandpaper followed by immediate sowing and sowing after $24 \mathrm{~h}$ were the most efficient treatments for overcoming dormancy in $S$. amazonicum seeds.
\end{abstract}

Index terms: tropical tree, germination, germination speed, hard seeds, dead seeds.

\section{MÉTODOS PARAA SUPERAÇÃO DE DORMÊNCIA EM SEMENTES DE Schizolobium amazonicum Huber ex Ducke (LEGUMINOSAE-CAESALPINIOIDEAE)}

RESUMO - Nas espécies tropicais a ocorrência de dormência é freqüente, causando germinação lenta e desuniforme. Para superar esta dormência tratamentos como escarificação em superfície abrasiva e água quente têm sido eficientes. O objetivo deste estudo foi quantificar a germinação sem tratamento (Experimento 1) e identificar métodos eficientes para superar a dormência em sementes de Schizolobium amazonicum Huber ex Ducke (Experimento 2). Foi estudado o efeito da escarificação manual em esmeril elétrico, água a 80 e $100^{\circ} \mathrm{C}$ e escarificação manual em lixa para madeira. A semeadura foi efetuada em substrato de areia e serragem. Foram quantificadas as porcentagens de germinação e de sementes duras e a velocidade de germinação. O delineamento experimental foi inteiramente casualizado. As análises estatísticas da germinação foram realizadas aos seis, nove, 12, 15, 18, 21 e 24 dias após a semeadura em esquema fatorial, juntamente com a análise de regressão. Para as demais variáveis foram efetuadas análise de variâncias e as médias

${ }^{1}$ Submetido em 13/03/2005. Aceito para a publicação em 14/07/2006;

${ }^{2}$ Eng. Agrônomo, MSc., Embrapa Amazônia Oriental, Caixa Postal 48, 
comparadas através do teste de Tukey. A germinação iniciou no sétimo dia e alcançou $90 \%$ aos 2310 dias após a semeadura (Experimento 1). Foi observada interação significativa entre tratamentos para superação da dormência e tempo de imersão em água após a escarificação (Experimento 2). Em geral, a imersão em água aumentou a germinação das sementes na maioria das avaliações. A análise de regressão foi significativa para todos os tratamentos, exceto na testemunha e imersão em água a $80^{\circ} \mathrm{C}$. A velocidade de germinação foi maior nas sementes escarificadas em superfície abrasiva (lixa e esmeril) e, nesses tratamentos, a germinação variou de 87 a $96 \%$, sem a presença de sementes duras. Sementes de S. amazonicum apresentam tegumento impermeável à água que impede germinação rápida e uniforme. Escarificação em esmeril elétrico seguido de semeadura imediata, escarificação em lixa com semeadura imediata e semeadura após 24 horas de imersão em água, foram os tratamentos mais eficientes na superação da dormência em sementes de S. amazonicum.

Termos para indexação: árvore tropical, germinação, velocidade de germinação, sementes duras, sementes mortas.

\section{INTRODUCTION}

Seed dormancy is a common phenomenon in tropical species (Knowles and Parrotta, 1995; Bruno et al., 2001), causing slow and non-uniform germination (Cruz et al., 2001). On the other hand, seed dormancy is recognized as a survival strategy, through which plants species avoid germination in unfavorable conditions (Fenner, 1993; Schmidt, 2000).

The impermeability of seed coat to water, or hardseededness, is a common mechanism of dormancy in Leguminosae (Rolston, 1978), but it is also found in several other families including Anacardiaceae, Bixaceae, Cannaceae, Convolvulaceae, Ebenaceae, Geraniaceae, Liliaceae, Malvaceae, Myrtaceae, Rhamaceae, Sapindaceae, Solanaceae and Zingiberaceae (Ballard, 1973; Atwater, 1980).

Several pretreatments have been proven efficient to overcome dormancy of Leguminosae seeds (Baskin and Baskin, 1998; Schmidt, 2000). The mechanical scarification on an abrasive surface has been used to overcome dormancy in many Leguminosae species. For example, in Hymenaea intermedia Ducke, 96\% of scarified seeds germinated in 26 days, while non-scarified seeds reached similar value only after 418 days (Cruz et al., 2001). In Bowdichia virgiloides Kunth, $79 \%$ of germination was obtained when seeds were scarified contrasting with $21 \%$ in the control treatment (Smiderle and Souza, 2003). In Sesbania sesban (L.) Fawc. $\&$ Rendle, germination was $82 \%$ when scarified compared to $68 \%$ in non-scarified seeds (Veasey and Freitas, 2002). Likewise germination in Senna occidentalis (L.) Link was $83 \%$ and $40 \%$, respectively (Delachiave and Pinto, 2003).

Immersion in hot water at temperatures ranging from 60 to $100^{\circ} \mathrm{C}$ is an efficient method of overcoming hardseededness (Bianchetti, 1981; Bianchetti and Ramos, 1981;
Bianchetti and Ramos, 1982a; Baskin and Baskin, 1998). Dimorphandra mollis Benth. seeds immersed in water at $100^{\circ} \mathrm{C}$ for two minutes attained a germination of $64 \%$, while germination of untreated seeds was $12 \%$ (Hermansen et al., 2000). Germination of Dinizia excelsa Ducke seeds scarified with water at $80^{\circ} \mathrm{C}$ for $10 \mathrm{~min}$, was $62 \%$, against $7 \%$ in the control treatment (Vastano Júnior et al., 1983). Mimosa scabrella Benth. seeds immersed in water at $90^{\circ} \mathrm{C}$ showed germination of $79 \%$, while in non-scarified seeds the germination was 17\% (Bianchetti, 1981). Immersion time should always be observed to avoid embryo death caused by heat exposure.

Schizolobium amazonicum Huber ex Ducke, Leguminosae - Caesalpinioideae, locally known as "paricá" is one of the 350 tropical wood species exploited in the Brazilian Amazon (Martini et al., 1998). It is native to the States of Pará and Amazonas (Ducke, 1949), presenting rapid growth and it is important in sliced veneer production (Falesi and Santos, 1996; Rosa and Pinheiro, 2001). It has been considered a promising species to the reforestation in the Amazon region (Rosa and Pinheiro, 2001). Presently in the Paragominas region (Pará), approximately 30,000 ha are planted with $S$. amazonicum and part of this area is being exploited.

According to Pereira et al. (1982) S. amazonicum seeds present high germination capacity without the need of any dormancy treatment. However, Maruyama and Ugamoto (1989) observed germination of only $28 \%$ at 23 days after sowing. Falesi and Santos (1996) reported germination in this species ranging from 4 to $96 \%$ after treatments to overcome dormancy. Maruyama and Ugamoto (1989) demonstrated that seeds of $S$. amazonicum have impermeable coats that delay germination. Bianchetti et al. (1997) evaluated the effect of several treatments to overcome dormancy in S. amazonicum 
seeds and observed germination ranging from 2 to $67 \%$.

The present study was designed to quantify $S$. amazonicum seed germination, without any treatment to overcome dormancy and to identify an efficient method of breaking seed dormancy in this species. The working hypothesis was that $S$. amazonicum seed germination is improved when seeds are subjected to treatments to overcome dormancy.

\section{MATERIAL AND METHODS}

Two experiments were carried out to study Schizolobium amazonicum Huber ex Ducke seed germination, at Embrapa Amazônia Oriental (1 $1^{\circ} 28^{\prime} \mathrm{S}$; 48 $\left.27^{\circ} \mathrm{W}\right)$, in Belém, Pará, Brazil, in 1995 and 2002. In both, seeds were left to germinate in a laboratory with no control over temperature and relative moisture.

Experiment 1 - Germination of untreated seeds Seed moisture was determined by leaving a random sample of 20 seeds in an oven set at $105 \pm 3^{\circ} \mathrm{C}$ during $24 \mathrm{~h}$ (Brasil, 1992). Germination type and seedling type were determined as Duke and Polhill (1981). Four replications of 100 seeds were sown at depth of $0.5 \mathrm{~cm}$ in sand and sawdust (1:1), previously sterilized in hot water $\left(100^{\circ} \mathrm{C}\right)$ for two hours and placed in plastic pots $(30 \times 22 \times 6 \mathrm{~cm})$. These were irrigated every two days. Germination, evaluated on four replications of 100 seeds, was quantified daily during 2310 days and the graphic was carried out considering all germinated seeds during intervals of 154 days. A seed was considered germinated when the first pair of true leaves was visible, with no noticeable seedling abnormalities.

Experiment 2 - Germination of scarified seeds - In this experiment the effects of the following treatments were evaluated: manual scarification on electric emery with immediate sowing $\left(\mathrm{T}_{2}\right)$ and sowing $24 \mathrm{~h}$ after immersion in unheated water $\left(\mathrm{T}_{3}\right)$; immersion in $80^{\circ} \mathrm{C}$ water for $2 \mathrm{~min}$ with immediate sowing $\left(\mathrm{T}_{4}\right)$; the same as $\mathrm{T}_{4}$ with sowing $24 \mathrm{~h}$ after the immersion $\left(\mathrm{T}_{5}\right)$; immersion in water at $100^{\circ} \mathrm{C}$ for $2 \mathrm{~min}$ and immediate sowing $\left(\mathrm{T}_{6}\right)$; the same as $\mathrm{T}_{6}$ with sowing $24 \mathrm{~h}$ after immersion in water $\left(\mathrm{T}_{7}\right)$; manual scarification on sandpaper and immediate sowing $\left(\mathrm{T}_{8}\right)$; the same as $\mathrm{T}_{8}$ and sowing $24 \mathrm{~h}$ after immersion in water at $29^{\circ} \mathrm{C}\left(\mathrm{T}_{9}\right)$. These treatments were compared with a control treatment $\left(\mathrm{T}_{1}\right)$. Seeds from the control treatment were not scarified or immersed in water. Seeds sown $24 \mathrm{~h}$ after treatment remained in water under ambient conditions of the laboratory. Electric emery scarification was performed at 3450rpm causing soft abrasion at the basal end of the seed for $2 \mathrm{~s}$. Scarification with sandpaper was carried out on 80 -grit sandpaper. The spot of manual scarification is showed on Figure 1. In the hot water treatments, four parts of water were used to one part of seeds. The $24 \mathrm{~h}$ immersion treatments used $400 \mathrm{~mL}$ of water to 210 seeds. Initial seed moisture was determined as in Experiment 1 (Brasil, 1992), but for a sample size of 25 seeds.

Sowing, substrate and environmental conditions were the same as in Experiment 1. Germination was quantified daily during 24 days as well as the percentage of abnormal seedlings and dead seeds (Brasil, 1992), the number of days to germination onset, the mean time of germination (Edmond and Draphala, 1958), and the germination speed (Maguire, 1962).

Data were subjected to the Brown \& Forsyth homogeneity of variance test (Statsoft, 1995) and an arcsine $\sqrt{(x+0.5) / 100}$ transformation was performed on mean germination time and percentage of abnormal seedlings. These transformed data were analysed in a completely randomized design with four replicates of 50 seeds each. The statistical analysis of germination percentage was carried out at $6,9,12,15,18,21$ and 24 days after sowing as a $4 \times 2$ factorial design (four types of scarification: electric emery, sandpaper, immersion in water in 80 and $100^{\circ} \mathrm{C}$ water; and

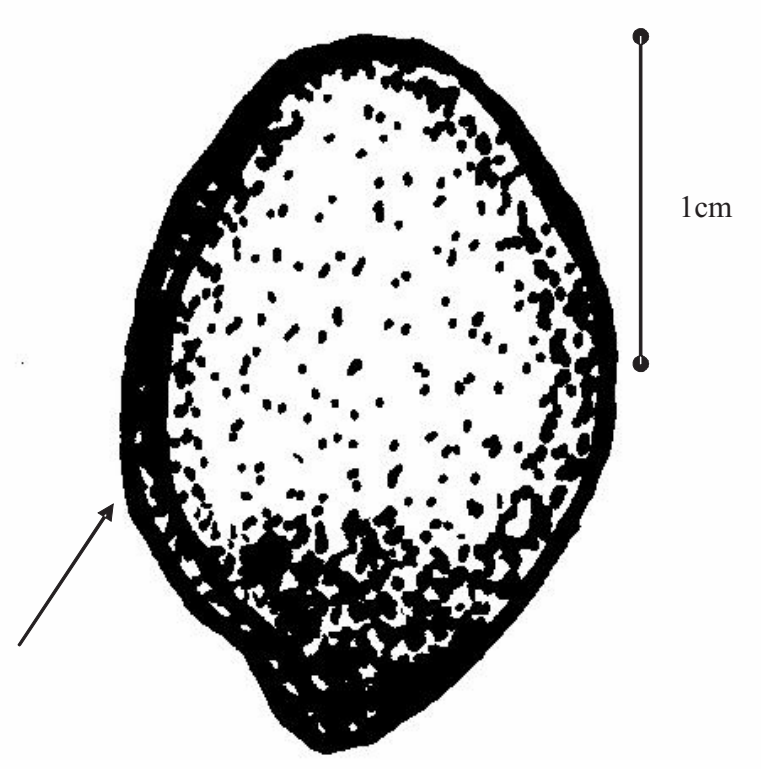

FIGURE 1. Schizolobium amazonicum seed. The arrow indicates the spot of manual scarification used in $T_{1}$. Belém, 2002. 
two sowing times: immediate and $24 \mathrm{~h}$ after the scarification treatments). Treatment means were compared by the Tukey test using Statistica (Statsoft, 1995). Data were backtransformed for presentation purposes.

\section{RESULTS AND DISCUSSION}

\section{Experiment 1 - Germination of untreated seeds} - Seed moisture content was 5.3\% ( \pm 0.2$)$, germination was epigeal and seedlings were phanerocotylar. Germination was non-uniform and slow, beginning 7 days after sowing. The whole germination process took 2310 days, when germination achieved $90 \%$ (Figure 2). Germination started with primary root development, achieving 5 to $7 \mathrm{~cm}$, when the hypocotyls began their development on the soil surface. Most seeds

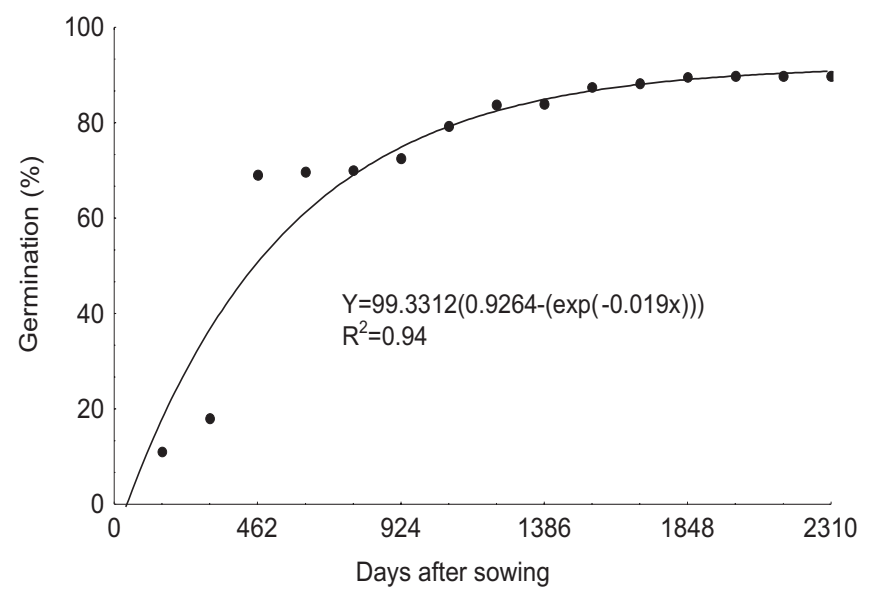

FIGURE 2. Germination of untreated Schizolobium amazonicum seeds. Belém, 2002. released their coats before hypocotyl development, though a small proportion of seeds kept their coat attached to the cotyledon, thus restraining seedling development. The germination curve was sigmoid (Tipton, 1984), with an initial phase of slow germination followed by a rapid increase in germination and a final phase presenting no significant germination increase, a pattern similar to the one reported for Micropholis cf. venulosa Mart. \& Eichler (Cruz et al., 2003). Long germination periods have been reported in Caesalpinioideae (Cruz et al., 2001).

Experiment 2 - Germination of scarified seeds - Seed moisture content at the start of the experiment was $11.3 \%$ $( \pm 2.2)$. There was interaction between scarification and postscarification treatments. In general, the germination of seeds immersed in water for $24 \mathrm{~h}$ was higher than the germination of seeds sown immediately after scarification (Table 1). Postscarification treatment also affected the onset of germination, which was higher than $40 \%$ on manually scarified seeds on the $6^{\text {th }}$ day, and nil on those sown immediately after scarification (Table 1). Twelve days after sowing seeds scarified on emery and sandpaper, but not immersed in water, there was similar or higher germination than in seeds scarified and immersed in water.

The regression analysis was significant for all treatments, for the control $\left(\mathrm{T}_{1}\right)$ and immersion in water at $80^{\circ} \mathrm{C}$ followed by immediate sowing $\left(\mathrm{T}_{4}\right)$, which showed 1 and $2 \%$ germination, respectively. These two treatments presented 97.5 and $96 \%$ hard seeds, respectively.

Seeds scarified on emery and sown immediately $\left(\mathrm{T}_{2}\right)$ showed significant increase in germination until the $15^{\text {th }}$ day (Figure 3A), whereas germination of seeds scarified and immersed in water occurred until the $9^{\text {th }}$ day (Figure 3B).

TABLE 1. Cumulative germination of Schizolobium amazonicum seeds at six, nine, 12, 15, 18, 21 and 24 days after immediate sowing (IS) and sowing $24 \mathrm{~h}$ after immersion in water.

\begin{tabular}{|c|c|c|c|c|c|c|c|c|}
\hline \multirow{2}{*}{ Treatments } & \multicolumn{2}{|c|}{6} & \multicolumn{2}{|c|}{9} & \multicolumn{2}{|c|}{12} & \multicolumn{2}{|c|}{15} \\
\hline & IS & 24 & IS & 24 & IS & 24 & IS & 24 \\
\hline Manual scarification on electric emery & $0.0 \mathrm{bA}$ & $43.5 \mathrm{aA}$ & $30.0 \mathrm{bB}$ & $84.0 \mathrm{aA}$ & $89.5 \mathrm{aA}$ & $86.5 \mathrm{aA}$ & \multicolumn{2}{|c|}{$95.5 \mathrm{aA} \quad 86.5 \mathrm{bB}$} \\
\hline Immersion in water at $80^{\circ} \mathrm{C}$ & $0.0 \mathrm{bA}$ & $1.5 \mathrm{aB}$ & $0.5 \mathrm{bC}$ & $8.0 \mathrm{aB}$ & $1.0 \mathrm{bC}$ & $19.5 \mathrm{aB}$ & \multicolumn{2}{|c|}{$1.0 \mathrm{bC} 25.0 \mathrm{aC}$} \\
\hline Immersion in water at $100^{\circ} \mathrm{C}$ & $0.0 \mathrm{bA}$ & $3.5 \mathrm{aB}$ & $5.5 \mathrm{aC}$ & $15.5 \mathrm{aB}$ & $11.5 \mathrm{bB}$ & $38.5 \mathrm{aB}$ & \multicolumn{2}{|c|}{$15.5 \mathrm{bB} \quad 56.0 \mathrm{aB}$} \\
\hline Manual scarification on sandpaper & $0.0 \mathrm{bA}$ & $40.5 \mathrm{aA}$ & $61.0 \mathrm{bA}$ & $89.0 \mathrm{aA}$ & $94.5 \mathrm{aA}$ & $91.5 \mathrm{aA}$ & \multicolumn{2}{|c|}{$94.5 \mathrm{aA} \quad 91.5 \mathrm{aA}$} \\
\hline \multicolumn{9}{|l|}{ TABLE 1 (continued). } \\
\hline \multirow{2}{*}{ Treatments } & \multicolumn{2}{|r|}{18} & \multicolumn{3}{|c|}{21} & \multicolumn{3}{|c|}{24} \\
\hline & IS & 24 & & IS & 24 & IS & & 24 \\
\hline Manual scarification on electric emery & $95.5 \mathrm{aA}$ & $86.5 \mathrm{bA}$ & & $95.5 \mathrm{aA}$ & $86.5 \mathrm{bAF}$ & & & $5 \mathrm{bAB}$ \\
\hline Immersion in water at $80^{\circ} \mathrm{C}$ & $1.0 \mathrm{bC}$ & $27.0 \mathrm{aC}$ & & $2.0 \mathrm{bC}$ & $28.5 \mathrm{aC}$ & & $\mathrm{bC}$ & $5 \mathrm{aC}$ \\
\hline Immersion in water at $100^{\circ} \mathrm{C}$ & $16.0 \mathrm{bB}$ & $70.5 \mathrm{aB}$ & & $20.0 \mathrm{bB}$ & $79.0 \mathrm{aB}$ & & $\mathrm{bB}$ & $5 \mathrm{aB}$ \\
\hline Manual scarification on sandpaper & $94.5 \mathrm{aA}$ & $91.5 \mathrm{aA}$ & & $94.5 \mathrm{aA}$ & $91.5 \mathrm{aA}$ & & $\mathrm{aA}$ & $5 \mathrm{aA}$ \\
\hline
\end{tabular}

Same capital letters in the column and lower case letters in the line, do no differ statistically at 5\% (Tukey). 

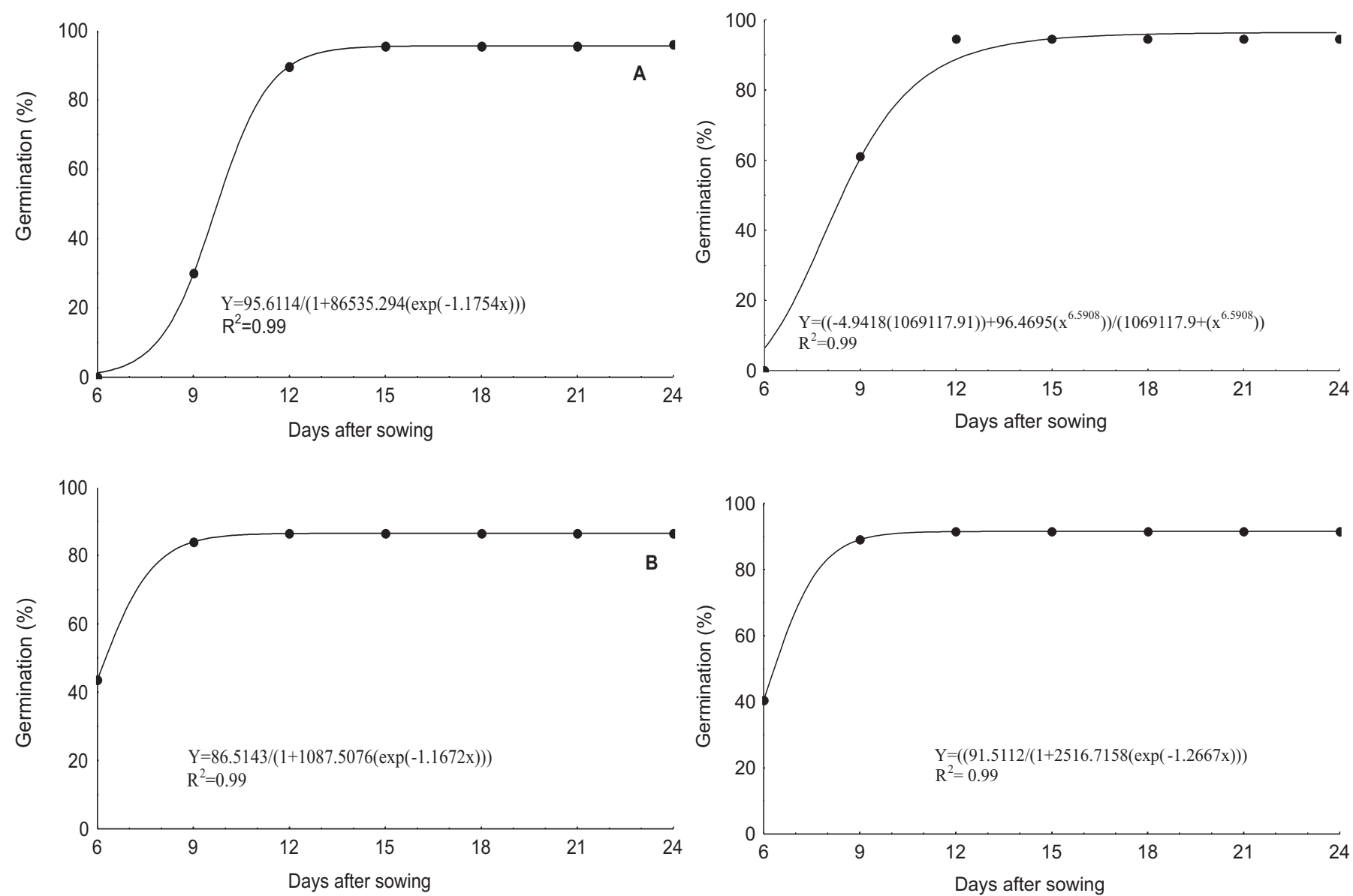

FIGURE 3. Germination of Schizolobium amazonicum seeds scarified on electric emery and followed by immediate sowing (A) and sowing after $24 \mathrm{~h}$ (B) in a sterilized 1:1 sand and sawdust mixture and left in uncontrolled conditions. Belém, 2002.

Scarification with sandpaper combined with immersion in water has been shown to increase germination of $S$. parahyba (Vell.) S.F. Blake (Lorenzi, 1992). Scarification on an abrasive surface was also an efficient method to overcome dormancy in H. intermedia (Cruz et al., 2001). In Peltophorum dubium (Spreng.) Taub. scarification on an abrasive surface was an efficient method of promoting seed germination, but germination was reduced when seeds were scarified for longer than 8s (Bianchetti and Ramos, 1982b). Seeds scarified on sandpaper showed a similar pattern of germination to seeds scarified on emery (Figure 4A and 4B).

Seeds scarified with water at $80^{\circ} \mathrm{C}$ and immersed in water for $24 \mathrm{~h}\left(\mathrm{~T}_{5}\right)$ presented the lowest final germination, reaching only $31.5 \%$ (Figure 5). Immersion in water at $100^{\circ} \mathrm{C}$ was not

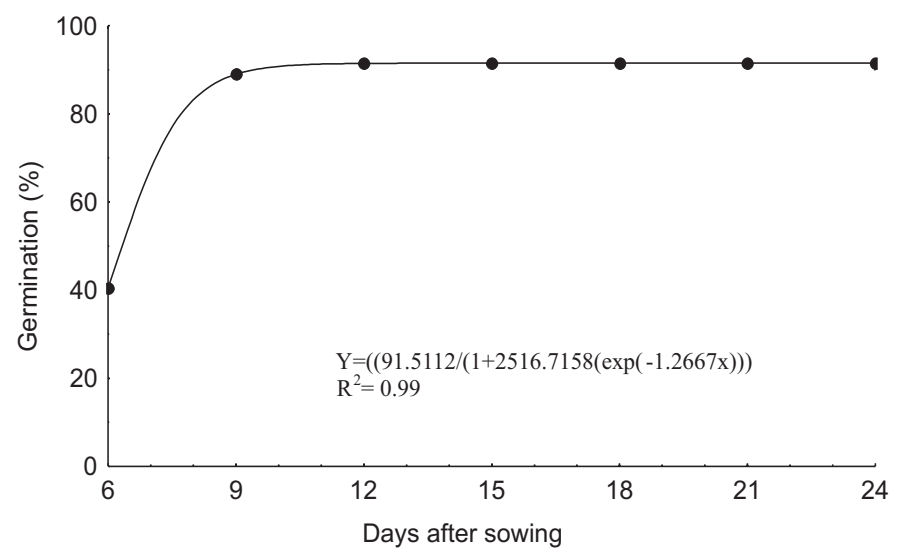

FIGURE 4. Germination of Schizolobium amazonicum seeds scarified on sandpaper followed by immediate sowing (A) and sowing after $24 \mathrm{~h}(\mathrm{~B})$ in a sterilized 1:1 sand and sawdust mixture and left in uncontrolled conditions. Belém, 2002.

so effective at promoting seed germination (Figure 6A), but when followed by a 24-hour water immersion period, germination reached $82.5 \%$ (Figure 6B).

The use of hot water to overcome dormancy in seeds with impermeable coats has been suggested for some forest species (Fowler and Bianchetti, 2000), but the efficiency of such a treatment depends on the species, water temperature and immersion time during scarification (Schmidt, 2000). The use of water at $80^{\circ} \mathrm{C}$ followed by immersion in water for $18 \mathrm{~h}$ has been recommended as an efficient treatment to scarify seeds of Acacia longifolia (Andrews) Willd. (Medeiros and Zanon, 1999) and M. bimucronata (DC.) Kuntze (Fowler and Carpanezzi, 1998). Higher water temperatures $\left(95-100^{\circ} \mathrm{C}\right)$ are an effective method for some species. In S. parahyba, seed 


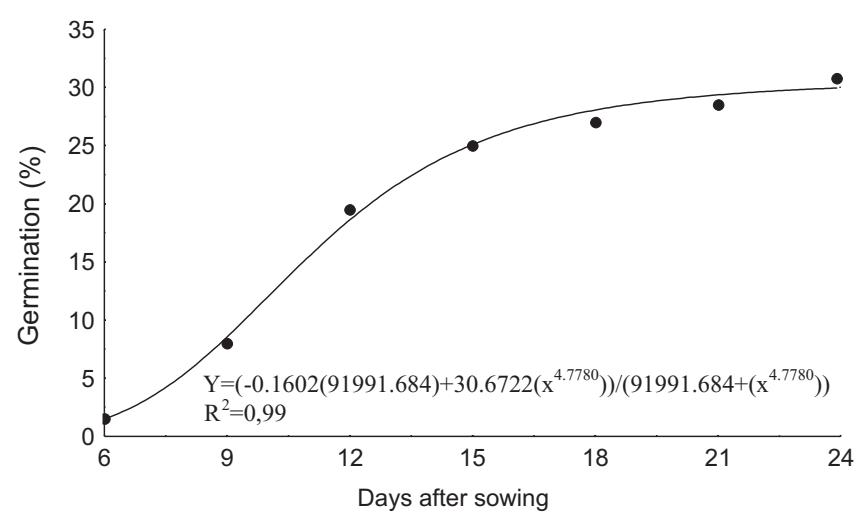

FIGURE 5. Germination of Schizolobium amazonicum seeds scarified in water at $80^{\circ} \mathrm{C}$ for $2 \mathrm{~min}$, left in water for $24 \mathrm{~h}$, sown in a sterilized 1:1 sand and sawdust mixture and left in uncontrolled room conditions. Belém, 2002.
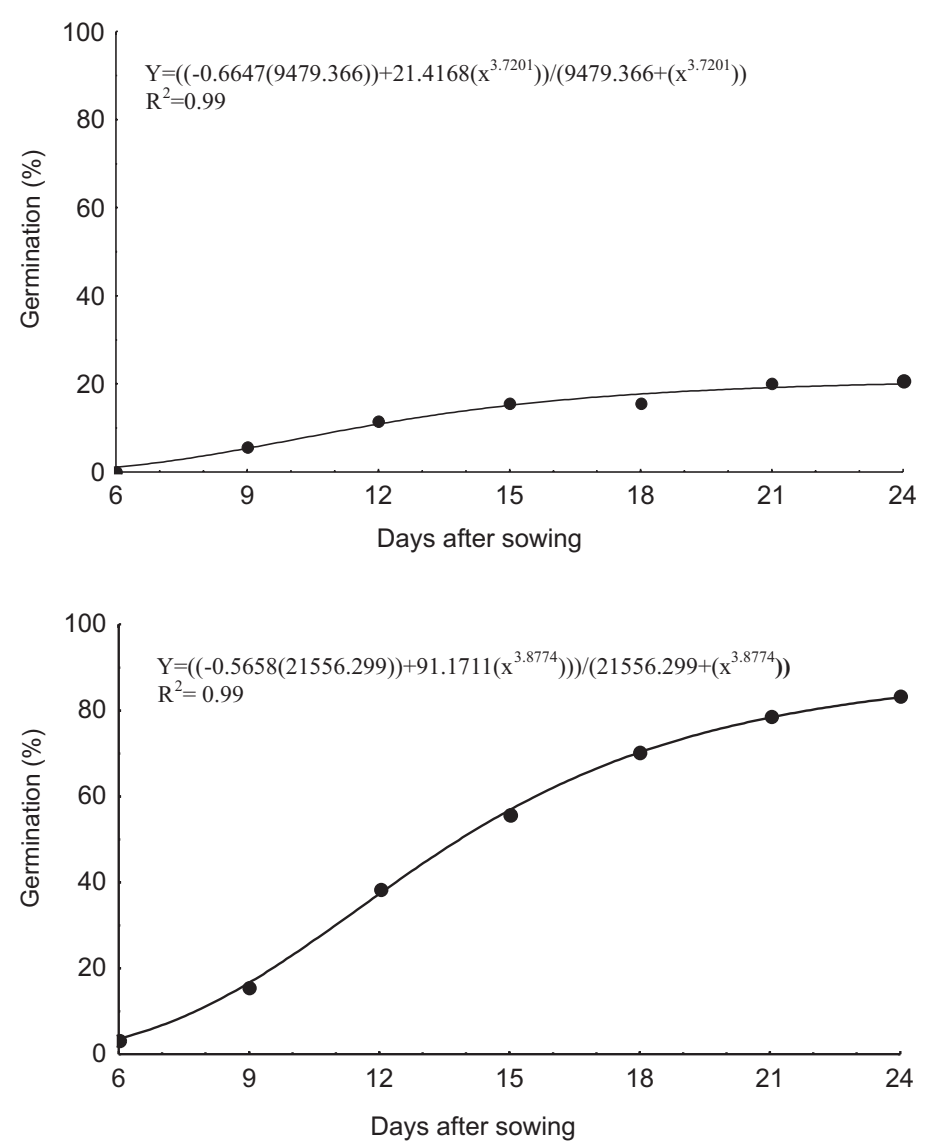

FIGURE 6. Germination of Schizolobium amazonicum seeds scarified in water at $100^{\circ} \mathrm{C}$ followed by immediate sowing (A) and sowing after $24 \mathrm{~h}(\mathrm{~B})$ in a sterilized 1:1 sand and sawdust mixture and left in uncontrolled room conditions. Belém, 2002. scarification in $95^{\circ} \mathrm{C}$ water during $4-10 \mathrm{~min}$ promoted germination, which ranged from 84.1 to $88.3 \%$ (Bianchetti and Ramos, 1981), while in Acacia mearnsii De Wild. 83.3\% germination occurred when seeds were scarified in water at $100^{\circ} \mathrm{C}$ for $6 \mathrm{~min}$ (Bianchetti and Ramos, 1982a). However, for $\mathrm{M}$. bimucronata the use of temperature above $80^{\circ} \mathrm{C}$ caused embryo death in some seeds (Fowler and Carpanezzi, 1998).

The Table 2 shows days to germination onset, mean germination time, germination speed index and germination, hard seed, dead seed, and abnormal seedling percentages. There were statistical differences among all treatments except for abnormal seedlings. In general, days to germination onset took 6-8 days after sowing corroborating the description by Pereira et al. (1982). However, when seeds were scarified in water at $80^{\circ} \mathrm{C}$ and sown immediately $\left(\mathrm{T}_{4}\right)$, germination started on the $13^{\text {th }}$ day. This treatment appears to delay the beginning of the germination process.

Mean germination time duration ranged from 6.6 days, when scarification was performed by sandpaper plus immersion water, to 14.8 days, when seeds were scarified in water at $80^{\circ} \mathrm{C}$ followed immediate sowing. Seeds scarified on emery $\left(\mathrm{T}_{3}\right)$ and sandpaper $\left(\mathrm{T}_{9}\right)$, followed by immersion in water, required fewer days to reach $50 \%$ of germination.

The germination speed index was higher for seeds scarified on emery $\left(\mathrm{T}_{3}\right)$ and sandpaper $\left(\mathrm{T}_{9}\right)$, with immersion in water, 6.56 and 6.78 , respectively, showing the efficiency of these treatments to speed up germination in S. amazonicum seeds.

The hard seed percentage was high in all treatments, except for the immersion in water $100^{\circ} \mathrm{C}$ with sowing after $24 \mathrm{~h}$ (T7) with $13 \%$ of hard seeds. In general, the dead seed percentage was low, except when seeds were scarified on emery and immersed in water (12.0\%).

Veasey and Freitas (2002) observed that treatments not only did not promote germination of Sesbania sesban (L.) Fawc. \& Rendle, S. rostrata Bremek. \& Oberm. and S. virgata (Cav.) Pers. but damaged a high number of seeds, but in $S$. parahyba, Bianchetti and Ramos (1981) did not detect any significant increase in dead seed percentage in treatments that did not promote seed germination.

Treatments tested in the present study did not increase the percentage of abnormal seedlings due to the small differences among them, typically, ranging from 0.7 to $3 \%$, and non-significant. 
TABLE 2. Number of days to germination onset (DGO), mean germination time (MTG), germination speed index (GSI), and germination (G), hard seeds (HD), dead seeds (DS) and abnormal seedlings (AS), in Schizolobium amazonicum.

\begin{tabular}{|c|c|c|c|c|c|c|c|}
\hline \multirow{2}{*}{ Treatments } & \multirow{2}{*}{ DGO } & \multirow{2}{*}{ MGT } & \multirow{2}{*}{ GSI } & G & HD & DS & AS \\
\hline & & & & $\%$ & $\%$ & $\%$ & $\%$ \\
\hline Control & $8.0 \mathrm{ab}$ & $9.5 \mathrm{abc}$ & $0.12 \mathrm{e}$ & $1.0 \mathrm{f}$ & $97.3 \mathrm{c}$ & $1.0 \mathrm{a}$ & $0.7 \mathrm{a}$ \\
\hline Manual scarification on electric emery with immediate sowing & $8.0 \mathrm{ab}$ & $10.3 \mathrm{bc}$ & $4.75 \mathrm{~b}$ & $96.0 \mathrm{a}$ & * & $1.0 \mathrm{a}$ & $3.0 \mathrm{a}$ \\
\hline Manual scarification on electric emery and sowing $24 \mathrm{~h}$ after & $6.0 \mathrm{a}$ & $6.7 \mathrm{a}$ & $6.56 \mathrm{a}$ & $86.5 \mathrm{bc}$ & $*$ & $12.0 \mathrm{~d}$ & $1.5 \mathrm{a}$ \\
\hline Immersion in water at $80^{\circ} \mathrm{C}$ with immediate sowing & $13.3 \mathrm{~b}$ & $14.8 \mathrm{c}$ & $0.10 \mathrm{e}$ & $2.0 \mathrm{f}$ & $96.0 \mathrm{c}$ & $2.0 \mathrm{ab}$ & * \\
\hline Immersion in water at $80^{\circ} \mathrm{C}$ with sowing 24 hours after & $6.5 \mathrm{a}$ & $12.8 \mathrm{bc}$ & $1.39 \mathrm{~d}$ & $31.5 \mathrm{~d}$ & $65.5 \mathrm{~b}$ & $0.5 \mathrm{a}$ & $2.5 \mathrm{a}$ \\
\hline Immersion in water at $100^{\circ} \mathrm{C}$ with immediate sowing & $8.2 \mathrm{ab}$ & $12.7 \mathrm{bc}$ & $0.88 \mathrm{de}$ & $20.0 \mathrm{e}$ & $71.0 \mathrm{~b}$ & $6.5 \mathrm{bc}$ & $2.5 \mathrm{a}$ \\
\hline Immersion in water at $100^{\circ} \mathrm{C}$ with sowing 24 hours after & $6.0 \mathrm{a}$ & $13.5 \mathrm{c}$ & $3.28 \mathrm{c}$ & $82.5 \mathrm{c}$ & $13.0 \mathrm{a}$ & $1.5 \mathrm{ab}$ & $2.5 \mathrm{a}$ \\
\hline Manual scarification on sandpaper with immediate sowing & $7.5 \mathrm{a}$ & $9.2 \mathrm{ab}$ & $5.20 \mathrm{~b}$ & $94.5 \mathrm{a}$ & * & $2.5 \mathrm{abc}$ & $3.0 \mathrm{a}$ \\
\hline Manual scarification on sandpaper with sowing 24 hours after & $6.0 \mathrm{a}$ & $6.6 \mathrm{a}$ & $6.78 \mathrm{a}$ & $91.5 \mathrm{ab}$ & * & $7.5 \mathrm{~cd}$ & $1.0 \mathrm{a}$ \\
\hline
\end{tabular}

Treatment means sharing the same letter within columns are not significantly different $(\mathrm{P}>0.05)$.

* Values omitted from variance analysis for being zero

\section{CONCLUSION}

Scarification either by electric emery or sandpaper, followed by immediate sowing and sowing after $24 \mathrm{~h}$, is the most efficient treatment to overcome dormancy in $S$. amazonicum seeds.

\section{ACKNOWLEDGMENTS}

The authors thank Walnice M.O. do Nascimento for the drawing and Moacyr B. Dias Filho for manuscript suggestions.

\section{REFERENCES}

ATWATER, B.R. Germination, dormancy and morphology of the seeds of herbaceous ornamental plants. Seed Science and Technology, Zürich, v.8, n.4, p.523-573, 1980.

BALLARD, L.A.T. Physical barriers to germination. Seed Science and Technology, Zürich, v.1, n.2, p.285-303, 1973.

BASKIN, C.C.; BASKIN, J.J. Germination of seeds with physical dormancy. In: Seeds: ecology, biogeography, and evolution of dormancy and germination. San Diego: Academic Press, 1998. p.101-132.

BIANCHETTI, A. Comparação de tratamentos para superar a dormência de sementes de bracatinga (Mimosa scabrella Benth.). Boletim de Pesquisa Florestal, Colombo, n.2, p.57-67, 1981.

BIANCHETTI, A.; RAMOS, A. Quebra de dormência de sementes de guapuruvu (Schizolobium parahyba (Vellozo) Blake). Boletim de Pesquisa Florestal, Colombo, v.?, n.3, p.69-76, 1981.

BIANCHETTI, A.; RAMOS, A. Comparação de tratamentos para superar a dormência de sementes de acácia-negra (Acacia mearnsii De Wild.). Boletim de Pesquisa Florestal, Colombo, n.4, p.101-111, 1982a.
BIANCHETTI, A.; RAMOS, A. Comparação de tratamentos para superar a dormência de sementes de canafístula (Peltophorum dubium (Sprengell) Taubert). Boletim de Pesquisa Florestal, Colombo, n.4, p.91-99, 1982b.

BIANCHETTI, A.; TEIXEIRA, C.A.D.; MARTINS, E. Tratamentos para superar a dormência em sementes de bandarra (Schizolobium amazonicum Huber ex Ducke). Colombo: Embrapa Florestas, 1997. 2p. (Comunicado Técnico, 20).

BRASIL. Ministério da Agricultura e Reforma Agrária. Regras para análise de sementes. Brasília: SNDA/DNDV/CLAV, 1992. 365 .

BRUNO, R.L.A.; ALVES, E.U.; OLIVEIRA, A.P.; PAULA, R.C. Tratamentos pré-germinativos para superar a dormência de sementes de Mimosa caesalpiniaefolia Benth. Revista Brasileira de Sementes, Campinas, v.23, n.2, p.136-143, 2001.

CRUZ, E.D.; MARTINS, F.O.; CARVALHO, J.E.U. Biometria de frutos e sementes e germinação de jatobá-curuba (Hymenaea intermedia Ducke, Leguminosae - Caesalpinioideae). Revista Brasileira de Botânica, São Paulo, v.24, n.1, p.161-165, 2001.

CRUZ, E.D.; CARVALHO, J.E.U. Biometria de frutos e sementes de curupixá (Micropholis cf. venulosa Mart. \& Eichler Sapotaceae). Acta Amazonica, Manaus, v.33, n.3, p.389-398, 2003.

DELACHIAVE, M.E.A.; PINHO, S.Z. Scarification, temperature and light in germination of Senna occidentalis seed (Caesalpinaceae). Seed Science and Technology, Zürich, v.31, n.2, p.225-230, 2003.

DUCKE, A. Notas sobre a flora neotrópica - II: as leguminosas da Amazônia Brasileira. Belém: Instituto Agronômico do Norte, 1949. 247p. (Boletim Técnico, 18).

DUKE, J.A.; POLHILL, R.M. Seedlings of Leguminosae. In: POLHILL, R.M.; RAVEN, P.H. (Ed.). Advances in legumes systematics. Kew: Royal Botanic Gardens, 1981. v.2, p.941-949.

EDMOND, J.B.; DRAPALA, W.J. The effects of temperature, sand and soil, and acetone on germination of okra seed. Proceedings of American Society for Horticultural Science, Geneva, v.71, p.428-434, 1958.

FALESI, I.C.; SANTOS, J.C. Produção de mudas de paricá - 
Schizolobium amazonicum Huber ex Ducke. Belém: FCAP/ Serviço de Documentação e Informação, 1996. 16p. (Informe Técnico, 20).

FENNER, M. Dormancy. In: Seed ecology. London: Chapman \& Hall, 1993. p.72-86.

FOWLER, J.A.P.; BIANCHETTI, A. Dormência em sementes florestais. Colombo: Embrapa Florestas, 2000. 27p. (Documentos, 40).

FOWLER, J.A.P.; CARPANEZZI, A.A. Tecnologia de sementes de marica (Mimosa bimucronata (DC) O. Ktze.). Boletim de Pesquisa Florestal, Colombo, n.36, p.47-56, 1998.

HERMANSEN, L.A.; DUREYA, M.L.; WEST, S.H.; WHITE, T.L.; MALAVASI, M.M. Pretreatments to overcome see coat dormancy in Dimorphandra mollis. Seed Science and Technology, Zürich, v.28, n.3, p.581-585, 2000.

KNOWLES, O.H.; PARROTTA, J.A. Amazonian forest restoration: an innovative system for native species selection based on phenological data and field performance indices. Commonwealth Forestry Review, London, v.74, n.3, p.230-243, 1995.

LORENZI, H. Árvores brasileiras: manual de identificação e cultivo de plantas arbóreas nativas do Brasil. Nova Odessa: Plantarum, 1992. 352p.

MAGUIRE, J.D. Speed of germination-aid in relation evaluation for seedling emergence vigor. Crop Science, Madison, v.2, n.2, p.176-177, 1962.

MARTINI, A.; ROSA, N.A.; UHL, C. Espécies de árvores potencialmente ameaçadas pela atividade madeireira na Amazônia. Belém: IMAZON, 1998. 34p. (Série Amazônia, 11).

MARUYAMA, E.; UGAMOTO, M. Treatments for promoting germination of Parkia oppositifolia Benth. and Schizolobium amazonicum Huber. Journal of Japanese Forestry Society, Tokyo, v.71, n.5, p.209-211, 1989.

MEDEIROS, A.C.S.; ZANON, A. Superação da dormência e sementes de acácia-marítima (Acacia longifolia). Colombo: Embrapa Florestas, 1999. 12p. (Circular Técnica, 32).

PEREIRA, A.P.; MELO, C.F.M.; ALVES, S.M. O paricá (Schizolobium amazonicum), características gerais da espécie e suas possibilidades de aproveitamento na indústria de celulose e papel. Silvicultura em São Paulo, São Paulo, v.16A, n.2, p.13401344, 1982.

ROLSTON, M.P. Water impermeable seed dormancy. The Botanical Review, New York, v.44, n.3, p.365-396, 1978.

ROSA, L.S.; PINHEIRO, K.A.O. Propagação vegetativa de estacas de paricá (Schizolobium amazonicum Huber ex Ducke) obtidas de material juvenil e imersas em ácido indol-3-butírico. Revista de Ciências Agrárias, Belém, n.35, p.79-88, 2001.

SCHMIDT, L. Dormancy and pretreatment. In: OLSEN, K. (Ed.) Guide to handling of tropical and subtropical forest seed. Humlebaek: Danida Forest Seed Centre, 2000. p.263-303.

SMIDERLE, O.J.; SOUZA, R.C.P. Dormência em sementes de paricarana (Bowdichia virgiloides, Kunth, Fabaceae Papilionoideae). Revista Brasileira de Sementes, Londrina, v.25, n.1, p.72-75, 2003.

STATSOFT. Statistica for windows. 2.ed. Tulsa: StatSoft, 1995. (General conventions and statistics).

TIPTON, J.L. Evaluation of three growth curve models for germination data analysis. Journal of American Horticultural Science, Mount Vermont, v.109, p.451-454, 1984.

VASTANO JÚNIOR, B.; BARBOSA, A.P.; GONÇALVES, A.N. Tratamentos pré-germinativos de sementes de espécies florestais amazônicas. I - Angelim pedra (Dinizia excelsa Ducke Leguminosae, Mimosoideae). Acta Amazonica, Manaus, v.13, n.2, p.413-419, 1983.

VEASEY, E.A.; FREITAS, J.C.T. Breaking seed dormancy in Sesbania sesban, $S$. rostrata and $S$. virgata. Seed Science and Technology, Zürich, v.30, n.1, p.211-217, 2002. 